\title{
F18 FDG PET uptake for the staging of Castleman disease and co-incidental uptake in lactating breast
}

\author{
Semra Paydas, Gulgun Buyukdereli, Melek Ergin, Aygul Polat Kelle, Erkut Erkurt \\ Cukurova University Facuty of Medicine Departments of Medical Oncology, Nuclear Medicine, Pathologyand Radiation \\ Oncology.
}

Correspondence: Semra Paydas. Address: Department of Oncology, Cukurova University faculty of Medicine, Adana, Turkey. Telephone: 90-322-3386-060. Email: sepay@cu.edu.tr

Received: August 24, 2011

Accepted: October 17, 2011

Published: December 1, 2011

DOI : $10.5430 /$ jhm.v1n1p57

URL: http://dx.doi.org/10.5430/jhm.v1n1p57

\begin{abstract}
Castleman Disease (CD) is an interesting and relatively rare lymphoproliferative disorder. The managemet of this entity depends to the presence of one or more than one foci. FDG PET is a novel diagnostic method to detect the unicentricity or multicentricity of the tumor. Here PET findings of a case with CD have been reported and co-incidental lactating breast uptake has been presented.
\end{abstract}

\section{Key words}

Castleman disease, FDG uptake, Lactating breast

\section{Case report}

A 37 year-old-woman was admitted to the hospital with a diagnosis of Castleman Disease (CD). Diagnosis had been done in another center and biopsy sample was re-evaluated by our pathologist (ME). She had a history of a mass in her left cervical region since 2 years. After detailed evaluation, an inscisional biopsy had been taken from this mass and this had been reported as CD hyaline vascular type. She had no history of systemic symptoms including fever, night swetas and weight loss. There was no evidence of autoimmune phenomena including hemolytic anemia, ANA positivity, hyperglobulinemia and high CRP levels.

Past medical history revealed a surgery for hypophyseal adenoma 4 years ago. She has a baby and breast feeding from her left breast only. She had the history of lactation from only left breast in all of her postpartum period. Physical examination showed a $4 \mathrm{~cm} \times 6 \mathrm{~cm} \times 9 \mathrm{~cm}$ hard, infiltrative mass in left cervical region. Other findings were unremarkable.

Laboratory: Hb was $12.3 \mathrm{~g} / \mathrm{dL}$, Hct was $37.4 \%$, WBC count was $4.78 \times 10^{9} / \mathrm{L}$, platelet count was $258 \times 10^{9} / \mathrm{L}$, ESR was $16 \mathrm{~mm} / \mathrm{h}$. Biochemical tests were within normal limits, except low HDL. Biopsy findings of the mass was compatible with CD-hyaline vascular type and biopsy showed numerous atrophic germinal centers that were circumferentially rimmed by small lymphocytes, and that within some of the germinal centers, there were ill-defined blood vessels. There was an extensive capillary proliferation within the affected lymph nodes. 
Immunohistochemically there was an increase in follicular dendritic cells detected by CD21 and atrophic germinal centers were found to be negative with Bcl-2 (Figure 1).

Clinical outcome: Clinically patient had unicentric CD. F18 FDG PET was taken to determine uni or multicentricity of CD. FDG PET showed soft tissue mass of $10 \mathrm{~cm} \times 6 \mathrm{~cm}$ in left cervical region and SUV max was found to be 6.5. In addition there was diffuse irregular F18 FDG uptake in left breast (Figure 2). This was reported as compatible with lactation. Other body structures did not show F18 FDG uptake. (The physician from the department of Nuclear Medicine (AK) assessed the patient before FDG study and she was breast feeding her baby from her left breast).

Figure 1. CD-hyaline vascular type: numerous atrophic germinal centers circumferentially rimmed by small lymphocytes, and ill-defined blood vessels

Figure 2. F18 FDG PET showing left cervical mass (Castleman disease) and left breast uptake (lactating breast)

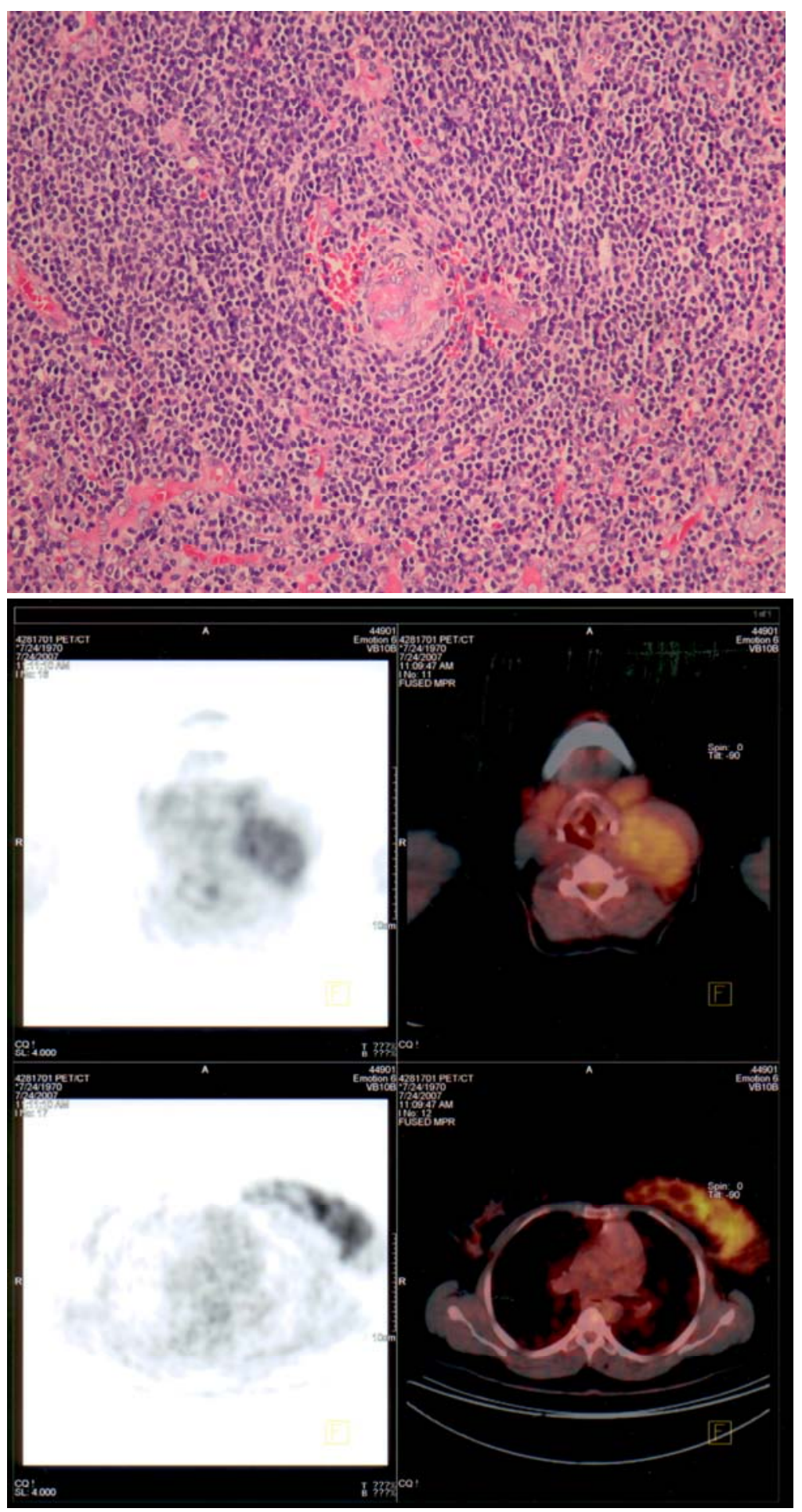

ISSN 1925-4024 E-ISSN 1925-4032 


\section{Discussion}

$\mathrm{CD}$ is a rare and interesting lymphoproliferative disease; inflammation is an important factor in the pathogenesis. There are 3 histological patterns: Hyaline-vascular, plasma cell and mixed variants. These subtypes correlate with clinical presentation: localized CD affects only one lymphoid region, generally there is no systemic symptoms and local therapies are generally curative. About $90 \%$ of cases with localized CD have hyaline-vascular type. Patients with multicentric CD have systemic symptoms, they need systemic therapy and they are older than localized forms. Plasmablastic or mixed types are the predominant pathologic patterns in these cases [1]. Our patient had hyaline vascular type CD and she had no systemic symptoms.

Due to the different therapeutic approaches and clinical outcome, it is important to detect the uni or multicentricity of this disease. In recent years there are some reports about the usefulness of this technology in cases with CD to determine the multicentricity and response to therapy. The essential point in the use of this entity is the inflammatory cells uptaking FDG [2-5]. Shortly, the first step in a case with CD is staging of the disease. We used FDG PET to determine whether this CD is uni or multicentric. We detected unicentric disease. Due to the infiltrative nature of the mass and difficulty to perform a surgery due to vital structures radiation therapy was planned.

Interestingly, we detected FDG uptake in left breast. It is known that avid upake of F18-FDG appears to be mediated by GLUT-1 transporter. The dose to glandular tissue has been found to be higher than the value for the non-lactating breast. It has been postulated that the, F18 activity is associated with the cellular elements in milk, mainly lymphocytes [6]. It is very well known that inflammatory cells may show increased FDG uptake and cause some mistakes mimicking malignant disorders. These conditions are thyroid uptake, uterine uptake during menstrual cycle, healing bones, joints, granulomatous reactions, atherosclerotic plaques, colonic polyps and G-CSF administration [7-13]. Increased breast uptake of FDG has been shown in lactating breast and this uptake has been attributed to suckling and it has been proposed that if PET scanning is planned, breastfeeding should be interrupted before the PET exam and afterward until the radioactivity has left the breast $[14,15]$. FDG uptake was detected in the left breast of our case lactating from this side. There was no evidence of inflammation and mass in left breast and her history confirmed the FDG uptake related with lactation. Additionally she is followed for 4 years and there is no evidence of tumor in the left breast.

Our case is interesting due to 2 reasons.

- We detected unicentric CD and we planned radiation therapy.

- $\quad$ Lactating breast showed FDG uptake.

In conclusion; a-The measurement of F18 FDG uptake is a reasonable way to determine the distribution of CD focus(es), b-FDG uptake in lactating breast is an interesting physiologic condition.

\section{Conflict of interest}

We declare that we have no conflict of interest.

\section{References}

[1] Bowne WB, Lewis JJ, Filippa DA, Niesvizky R, Brooks AD, Burt ME, Brennan MF. The management of unicentric and multicentric Castleman's disease. Cancer. 1999;85:706-17. http://dx.doi.org/10.1002/(SICI)1097-0142(19990201)85:3<706:AID-CNCR21>3.0.CO; 2-7

[2] Robinson H, Prince HM, Ramdave S, Seymour JF, Elliott P, Hicks R. Preliminary experience of 18F-fluorodeoxyglucose positron emission tomography in Castleman's disease. Leuk Lymphoma. 2006;47:2664-66.

http://dx.doi.org/10.1080/10428190600947826. Ajh 1. Murphy SP, Nathan MA, Karwal MW. FDG-PET appearance of pelvic Castleman’s disease. J Nucl Med. 1997;38:1211-12. PMid: 9255152. 
[3] Blockmans D, Maes A, Stoobants S, Bobbaers H, Mortelmans L. FDG positron emission tomographic scintigraphy can reveal Castleman's disease as a cause of inflammaion. Clin Nucl Med. 2001;26:975-76. PMid: 11595872. http://dx.doi.org/10.1097/00003072-200111000-00034

[4] Kunishima S, Taniguchi H, Koh T, Yamaguchi A, Yamagishi H. F-18 fluorodoxyglucose positron emission tomography in mesenterial Castleman’s lymphoma. Clin Nucl Med. 2001;26:789-90. PMid: 11507303. http://dx.doi.org/10.1097/00003072-200109000-00014

[5] Reddy MP, Graham MM. FDG positron emission tomography imaging of thracic Castleman’s disease. Clin Nucl Med. 2003;28:325-26. PMid: 12642717. http://dx.doi.org/10.1097/00003072-200304000-00015

[6] Towson JBC. Radiation dosimetry and protection in PET. In: Walka PE, Bailey DL, Townsend DW, Maissey MN. Positron Emission Tomography Tokyo. 2003,266-79.

[7] Kang KW, Kim SK, Kang HS, Lee ES, Sim JS, Lee IG, Jeong SY, Kim SW Prevalence and risk of cancer of focal thyroid incidentaloma identified by $18 \mathrm{~F}$-fluorodeoxyglucose positron emission tomography for metastasis evaluation and cancer screening in healthy subjects. J Clin Endocrinol Metab. 2003;88:4100-04. http://dx.doi.org/10.1210/jc.2003-030465

[8] Chander S, Meltzer CC, McCook BM: Physiologic uterine uptake of FDG during menstruation demonstrated with serial combined positron emission tomography and computed tomography. Clin Nucl Med. 2002;27:22-24. PMid: 11805479. http://dx.doi.org/10.1097/00003072-200201000-00005

[9] Abouzied MM, Crawford ES, Nabi HA: 18F-FDG imaging: Pitfalls and artifacts. J Nucl Med Technol. 2005;33:145-55. PMid: 16145222.

[10] Cherk MH, Pham A, Haydon A. 18F-fluorodeoxyglucose positron emission tomography-positive sarcoidosis after chemoradiotherapy for Hodgkin's disease: a case report. J Med Case Reports. 2011;29:247. PMid: 21714863. http://dx.doi.org/10.1186/1752-1947-5-247

[11] Abdul H, Abdul N, Nordin A. Dual time point imaging of FDG PET/CT in a tuberculous spondylodiscitis. Biomed Imaging Interv J. 2010;6:e18.

[12] Coffey JP. The role of 18FDG-PET in the detection of early cancers and precancerous polyps in colorectum. Nucl Med Commun. 2010;31:341. PMid: 20375975. http://dx.doi.org/10.1097/MNM.0b013e3283346554

[13] Hanaoka K, Hosono M, Usami K, Tatsumi Y, Yamazoe Y, Komeya Y, Tsuchiya N, Ishii K, Sumita M. Fluorodeoxyglucose uptake in the bone marrow after granulocyte colony-stimulating factor administration in patients with non-Hodgkin's lymphoma. Nucl Med Commun. 2011;32:678-83. PMid: 21499162. http://dx.doi.org/10.1097/MNM.0b013e328346b32a

[14] Hendler D, Stemner SM. Uncommon reason for high Fluorodeoxyglucose positron emission tomography uptake. J Clin Oncol 2010;28:659-60. PMid: 20713861. http://dx.doi.org/10.1200/JCO.2010.29.5543

[15] Rodney J. Hicks, David Binns, and Michael G. Stabin. Pattern of Uptake and Excretion of 18F-FDG in the Lactating Breast. J Nucl Med. 2001;42:1238-42. PMid: 11483686. 